\title{
Production and Logistics Performance of Czech and Slovak Companies
}

\author{
Bobák Roman, Pivodová Pavlína, Poláková Veronika
}

\begin{abstract}
This contribution deals with the issues of production and logistics performance of Czech and Slovak companies. The goal of the research was to analyze logistic processes, methods of industrial engineering, methods and evaluation of manufacturing, software tools utilized for measurement and management of performance, which are currently applied in manufacturing companies in the Czech and Slovak Republic. This analysis was done with the utilization of qualitative research conducted in 80 selected manufacturing companies in 2009. The results are compared in the continuity with the conclusions from previous researches on manufacturing and logistic factors of the competitiveness of Czech industrial manufacturers carried out during the period 2000-2001 in the framework of the research project of the Faculty of Economics and Management completed in 2004 .
\end{abstract}

Key words: Competitiveness, Logistics Industrial Performance, Industrial Engineering, Metrics

\section{CURRENT STATE OF KNOWLEDGE}

The concept of competitiveness (or ability to compete) is defined in the theoretical economic literature in the macroeconomic dimension predominantly as gaining a comparative advantage (Smith, 1958 , Ricardo, 1958, Samuelson, 2005). In the publication Time Based Competition (Blackburn, 1994) and Dynamic Manufacturing (Hayes, Wheelwright) which is relatively well known in this country, we can find the definition of competitiveness from the report of the Presidential Commision of the USA for competitiveness of the industry from 1985. „A nation's competitiveness is the degree to which it can, under free and fair market conditions, produce goods and services that meet the test of international markets while simultaneously expanding the real incomes of its citizens" (Report of the Presidential Commision of the USA, 1984).

When looking for the meaning of the concept of competitivness of a manufacturer in the microeconomic (corporate) field, most authors tend to see it as gaining the competitive advantage in the turbulent market environment through the leading position in lower costs or diferentiation in products (utility and quality of product), function (customer service, delivery terms) in process (marketing, manufacture, innovation). "The source of the competitive advantage is the multitude of individual activities, which the company performs within the life cycle of the product and which can be represented by the value chain. Each of these activities contributes to the relative position of the company as for the amount od expenses and creates a basis for the differentiation" (Porter, 1995). In this sense the source of the ability to compete are all activities of the company leading to the use of the products and services in the markets and increase of the value of acquired means; this creates close connection with the synthetic quantification of productivity as the relation of output (financial, profit, turnover) and input (actual number of employees, time fond, financial expenses and capital) of company activities. Tomek (1999) characterizes the abil- 
ity to compete of the manufacturere as the array of capabilities of the company (manufacturer) effectively setting up production, manufacturing and selling competitive products in such a way that this assures its long-term strategic goals even under competition from other manufacturers of products that meet the same needs while participating in the total offer. These capabilities can be divided into following five basic partial groups:

- The capability to develop and prepare products capable to compete

- The capability to produce these products,

- The capability to sell these products,

- The ability to secure the above capabilities financially and economically,

- The ability to manage the above capabilities effectively.

In a global economy and in competitive and dynamic environment, logistics is an important strategic factor for encreasing competitiveness. Stevenson (2007) defines logistics as follows: logistics refers to the movement of materials, services, cash, and information within a facility and to incoming and outgoing shipments of goods and materials in a supply chain (SC). Logistics management is the part of the SC involved with the forward and reverse flow of goods, services, cash, and information. Logistic management includes management of inbound and outbound transportation, material handling, warehousing, inventory, order fulfilment and distribution, third-party logistics, and reverse logistics. Reverse logistics is the backward flow of goods returned to the SC.

The logistics utilizes a complex and integrated (systemic) approach to the analysis of material flows that are interconnected both horizontally and vertically and form material chains; these hains can be detached, examined and modeled in a variety of ways. The methodical basis of perfecting the material processes is in this aspect identical also with the methods of industrial engineering.

Logistics as a operationally economic and as a cross-sectional function runs across operationally economic areas:

- Logistics should connect the material, space and time differentiation of manufacture and consumption on contact points within companies and between them logically and economically; to each process of division of labor there is a corresponding process of labor interconnection,

- Logistic processes are processes of transfer for spaning space and time, which in the specific case of commodity economy are transportation, transfer and warehousing processes portrayed as logistic processes (Kortchak, 1995),

- Logistic management is a sphere of activity of the corporate management responsible for planning, managing and supervising physical, logistic processes on the strategic and operative levels supported by flexible organizational forms that promote holistic integrated concept of (Gros, 1995, Sixta, 1999, Pernica, 1994),

- The purpose of logistic optimization rests on the reduction of inefficiencies and in the analysis of the economy of the entire course of movement of the material and commodity.

Consequences of improvement of the logistic performance are: a better level of services and attitudes towards the customer, reduction of fixed funds, of warehousing and transportation costs through logistic chain. Integrated logistics includes total material flow and flow of data that are necessary for planning and managing of the flow of materials. 
The overview of application fields of industrial engineering that steps into rationalization of company activities, not only manufacturing alone, and in the direction of removal of all forms of waste is characterized in the classic methods of continuous improvement focusing particularly on operating (manufacturing) management (Vytlačil et al., 1997). Other autors emphasize a more complex version, expressing the innovation nature of projecting of changes in all corporate processes with the utilization of process and reeingineering aproaches . (Warnecke, Košturiak et al., 2000).

The application of the methods of industrial engineering, has too a fundamental importance not only in the case of classical tools for reducing resources invested for securing of the manufacturing process and indirectly reduction of costs, but also for increasing flexibility of processes of pre-production and production phases. In contrast to logistic approaches, which stress primarily material and information side of corporate processes on the technical, information and communication level, the approaches of industrial engineering distinctly focus on the active role of the human as an innovator of all industrial processes. Perspective directions of the developments of methods of logistics and industrial engineering lead to the creation of interconnected selforganizing and self-optimizing interpreneurial networks operating in the principle of fractal enterprises. The distinctive element of integration besides the material flows become information and communication technologies supporting utilization of elements of knowledge management (Warnecke, 2000, Jirásek, 2002, Zelený, 2000).

To attain higher levels of integration it is possible to use a number of approaches, philosophies and methods. The following resources are cruicial for that:

- Just-in-Time, Suply Chain Management and Customer Relations Management as a complex system of an effective solution of the relationship betwee suppliers and customers in the entire logistic network (WCL = World Class Logistics), (Dilworth, 1993, Vytlačil, Mašín, 1996, Košturiak, Gregor, 1997, Fiala, 1999).

- Total Quality Management (Vytlačil et al., 1998).

- Improving the relationship human-machine with utilization of principles TPM, elimination of defects POKA-YOKE, autonomy of workplaces JIDOKA, and of visual management (Vytlačil, Mašín 1996, 1997, 1999).

- KAIZEN, gradual improvement of processes and elimination of weste postupné zlepšování procesů a eliminace wastefulness with the utilization of work teams and moderation as creative way to solve problemss (Vytlačil, Mašín 1996, 1997, 1999).

- Simultaneous engineering and a system of rapid changes SMED for shortening preparatory and service times (Fiala, 1999, Gregor et al., 1997).

- Reengineering and structured management with utilization of management according to the goals and BSC (Hammer, 1998, Kaplan, 2000).

- Fractal factory (Warnecke et.al, 2000).

All above-mentioned approaches and methods are included in the charaterized spectrum of logistic approaches and methods of industrial engineering.

A great number of studies also deal with the relationship between the utilization of supply chain management, of JIT, KAIZEN, ... and their effect on the performance of a company. The majority of empirical surveys on supply chain integration report a positive relationship between in- 
tegration and performance (Van der Vaart and van Donk, 2008). De Toni and Nassimbeni (1999) found that better performing plants exhibit a higher level of logistical interactions, Frohlich and Westbrook (2001) found that the widest arcs of integration had the strongest association with performance improvement, Sheu et al. (2006) found that higher levels of collaboration result in operational Performance in the supply chain systém. Li et al. (2009) found that supply chain integration is significantly related to supply chain performance. Prajogo, J. Olhager (2012) showed that both information and material flow integration are important for supply chain integration, having significant effects on performance.

\section{THE RESEARCH METHODOLOGY AND THE IDENTIFICATION OF RESEARCH QUERIES}

Within the scope of research supported by the project of the Grant Agency of the Czech Republic GAČR 402/09/1739 "Development of the model for measuring and management of the performance of companies" a quantitative research was done by means of a questionnaire regarding measuring and managing of the company performance. A total of 402 companies participated in the entire quantitative research. A select group of 80 respondents from the manufacturing sphere was requested to aswer additional questions beyond the framework of the basic questionnaire. These included a more detailed qualitative survey pertaining mainly to the content of manufacturing and logistic processes taking place in the organization, manufaccturing and logistic factors affecting the company performance. Additional entries included methods and metrics of management and mesurement of manufacturing and logistic performance, extent of actual and planned realization of methods of industrial engineering in organizations.

The goal of the research was to get answers to the following research questions:

1. What logistic processes take place in manufacturing companies in the Czech Republic and Slovak Republic?

2. What methods of industrial engineering are currently applied in the manufacturing companies in the Czech Republic and Slovak Republic?

3. What methods and metrics for measuring manufacturing and logistic Performance are used in the manufacturing companies in the Czech Republic and Slovak Republic and how satisfied are managers with them? What kind of metrics are used for the measurements of internal proceses in the company?

4. What software tools are being used for the measuring of performance by the manufacturing companies in the Czech Republic and Slovak Republic?

The results from this research are compared with results from similar programs for researching the competitiveness of Czech industrial manufacturing companies that took place in the time period 2000-2001 as the part of the research design of the Faculty of Management and Economics (FaME) (Trnka, 2004).

The research of manufacturing and logistic performance was carried out in manufacturing companies in the years 2001 and 2009. More detailed characteristics of the files are in Table 1. It is evident that the the representation of companies is evenly distributed between small, middle and large companies. 
Tab. 1 - Characteristics of freequency and \% of distribution of researched files. Source: own

\begin{tabular}{|l|c|c|c|c|c|}
\hline \multirow{2}{*}{} & \multirow{2}{*}{} & \multicolumn{4}{|c|}{ Number of employees } \\
\cline { 3 - 6 } & & \multicolumn{2}{|c|}{2001} & \multicolumn{2}{c|}{2009} \\
\cline { 3 - 6 } & & fte & $\%$ & fte & $\%$ \\
\hline Micro companies & $<10$ & 2 & $6 \%$ & 3 & $4 \%$ \\
\hline Small companies & $10-49$ & 10 & $28 \%$ & 22 & $28 \%$ \\
\hline Medium companies & $50-249$ & 13 & $36 \%$ & 25 & $31 \%$ \\
\hline Large companies & $>250$ & 11 & $31 \%$ & 30 & $38 \%$ \\
\hline Total & & 36 & $100 \%$ & 80 & $100 \%$ \\
\hline
\end{tabular}

\section{RESULTS AND DISCUSSION}

\subsection{Logistic processes in companies}

In the qualitative research was used categorization of logistic activities performed in organizations (Schulte, 1994, Gros, 1996). The goal was to compare the attained results with the outputs of the research performed in 2001 in manufacturing organizations in the Zlín region (Bobák, 2004).

Continuous monitoring of suppliers Confirming delivery

Transport, storage of raw materials Placing orders Consideration of supply Deciding on suppliers Organization tender Search sources of supply Develop a plan of supply Deciding the purchase of $\mathrm{X}$ Storage inventories of work in progress

Control of internal transport

Determination of semi-finished stocks

ORV support manufacturing operations Ensuring the supply of materials and energy Determination of production materials consumption MTZ

Community Planning Program

The choice of distribution channels Implementation of business operations

Providing transportation

Packaging, storage, assembly, shipping Inventory management and deployment Monitoring the performance of the term ordered Security Income orders

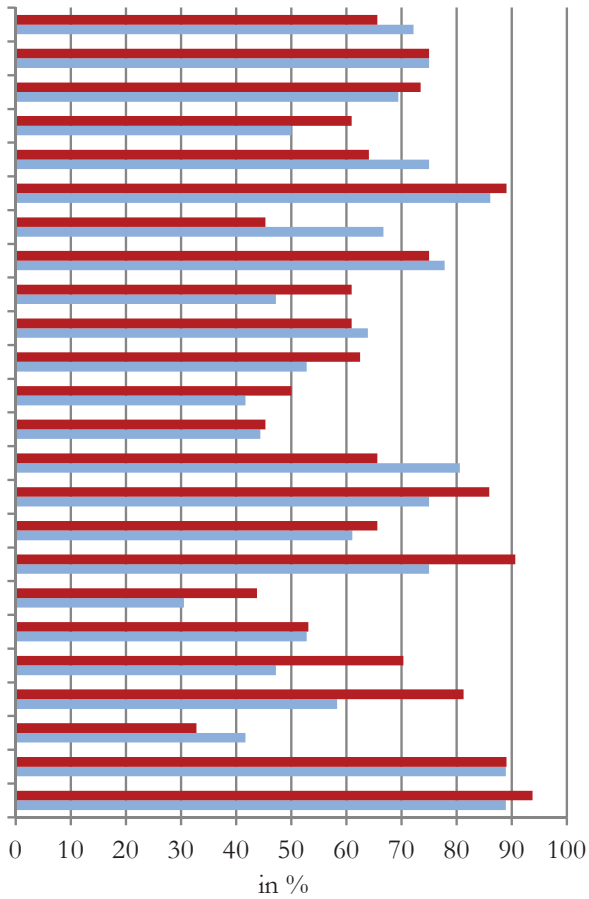

$2009-2001$

Fig. 1 - Performed logistic activities. Source: own 
Figure 1 shows that the most frequent activities include securing the receipt of orders, monitoring dates of delivery, packaging, warehousing, completing, shipping, planning of the production program, securing supply of materials and energy and decisions about suppliers were implemented in 2009 by $80 \%$ of companies participating in the research. In comparison with the year 2001 it was found that there was some moderate increase of some activities tied in with the distribution logistics, such as packaging, warehousing and securing transport, and selection of distribution routes. An increase of frequencies was observed also in planning of production program, in setting up a plan of supply and placement of orders. On the other hand, some frequencies were reduced in 2009, such as support of production operations and organization of the bidding process. In a sample of 2009 is about $15 \%$ companies that are engaged in the production of outside business or services.

\subsection{Implementation of industrial engineering methods in organizations}

One part of the qualitative research were structured interviews regarding the application of methods of industrial engineering (IE) based on statements in the scale: being used, planning to use and do not plan using it (see Figure 2). Results were compared with previous research done in 2002, which was focusing on selected companies of the rubber and plastics industry, mechanical engineering industry and electrical industry with a number of employees over 1000 and and annual turnover of 250 millions CZK. ('Tuček, 2002).

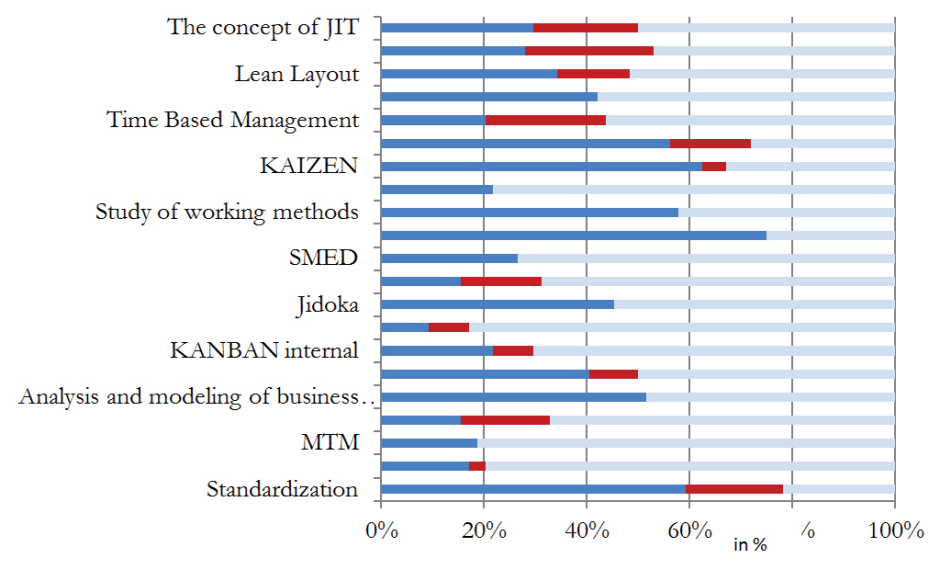

We use $\mathbf{W}$ We do not use, but we plan to use $\square$ We do not use, we do not plan to use

Fig. 2 - Application od selected methods of IE in organizations. Source: own

The research performed in 2009 has shown that more than one half of companies use the method Standardization (59\%), Analysis and modelling of business processes (52\%), TPM (75\%), Stady of working methods (58 \%), KAIZEN (63\%), Teams (56\%). More than 1/3 companies still use 5S, Jidoka, Visual Management, Lean Layout. Other methods of industrial engineering are used on a smaller scale. The research performed in 2009 has shown a lower degree of applications of industrial engineering in comparison to the research done in 2002. This drop was sharp 
mainly in the use of the methods Poka-Yoke, Moderation, Time Based Managementu, Lean Layout and of concept JIT. On the other hand more pronounced increase was observed in the use of the method Analysis and Modelling of Business Processes and method TPM. Comparison of methods of industrial engineering in time is not accurate because of the utlization of a diffrent sample of companies. In 2002 the research was performed in larger companies, in which a more frequent implementation of methods of industrial engineering.

\subsection{Methods and metrics for measuring manufacturing (operational) and logistics performance}

The investigation confirmed a wide spectrum of methods suitable for the evaluation and measurement of production and logistic (operating) performance of organizations. The frequency of current utilization of the methods and satisfaction with their utilization was evaluated on a scale of 0 (insignificant) to 3 (very significant) (see Figure 3).

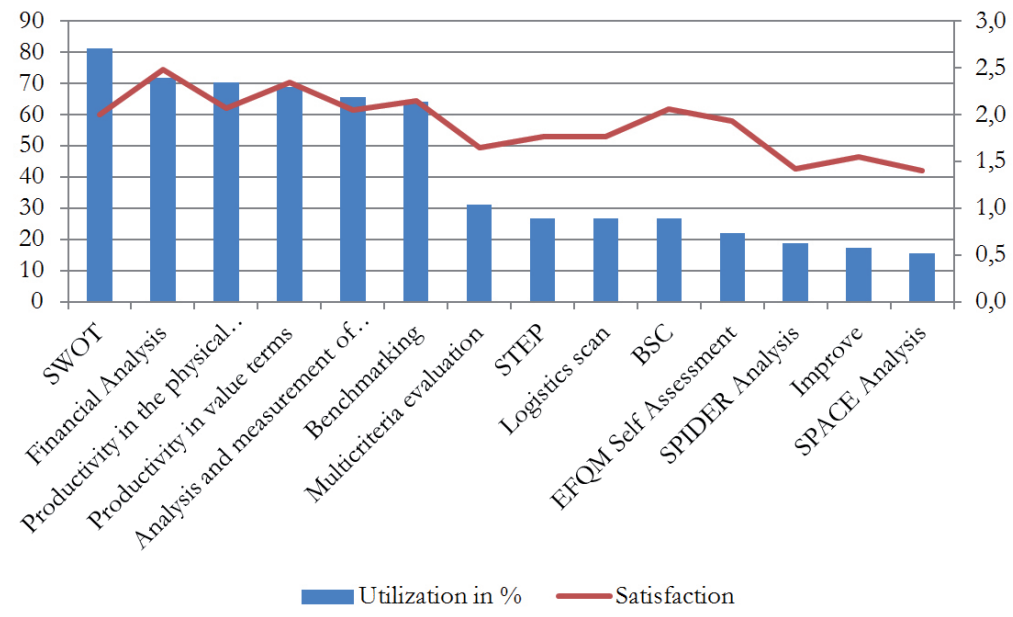

Fig. 3 - Frequency of used methods and satisfaction with their utilization. Source: own

The most notable is the frequency of SWOT analysis from the category of common analytical methods that are used in $80 \%$ of analyzed companies. Then the next is the utilization of index system of evaluation of productivity, analysis and measuring of labor, financial analysis and benchmarking comparison from multicriterail methods of scale evaluation. Other methods are utilized in less than $1 / 3$ of the companies. The development of satisfaction with individual methods is interesting. In general it can be seen that more frequently used methods are correlated with a higher satisfaction of the users. The exception are concepts BSC and EFQM, which are not utilized too often, but the satisfaction with their use is relatively high.

As for the criteria for internal processes of the performance of companies (see Figure 4), the most widely are used the criteria of costs of internal processes ( $76 \%$ of companies), performance of internal processes ( $56 \%$ podniků), number of emplyees involved in internal processes $(55 \%)$, 
duration of the process (45\%), size of inventory (39\%), profitability of internal processes $(34 \%)$. Other analyzed criteria were utilized by less than one third of companies.

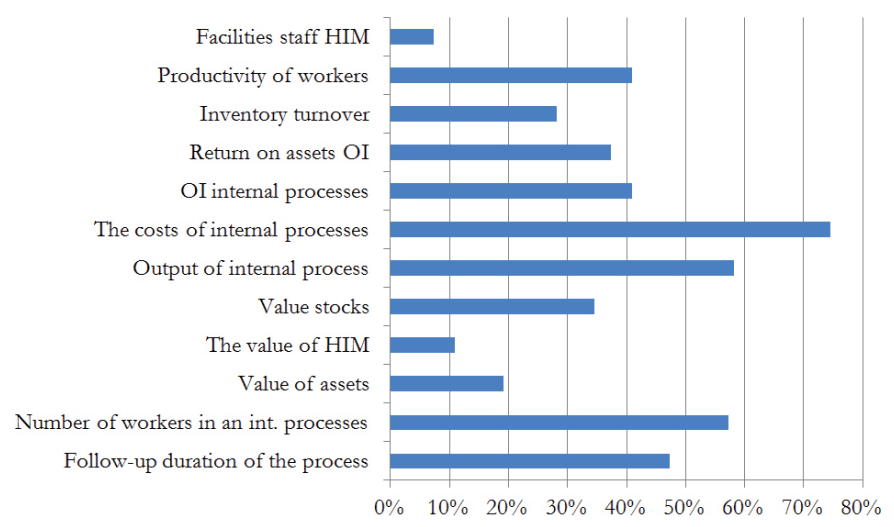

Fig. 4 - Standards for performance of internal processes. Source: own

\subsection{SW support of measuring of manufactury and logistic performance}

Measuring of production and logistic performance is demanding as to the acquisition of information. Therefore the support of index systems of measuring the performance by information systems and technologies is important. In this context the software support by various tools and their combinations was subject of the questionnaire investigation.

Submitted data of the overall files and evaluated results of the qualitative research differ because of different methods of evaluation by a combination of more systems; the combination Excel and ERP were predominant (see Figure 5). Less used are the methods of management information systems (MIS), corporate performance management (CPM) and software tools to support the creation of process maps. These results are consistent with other published outcomes of Faculty of Management and Economics in this area (Škodáková et al, 2008, Knápková et al, 2011).

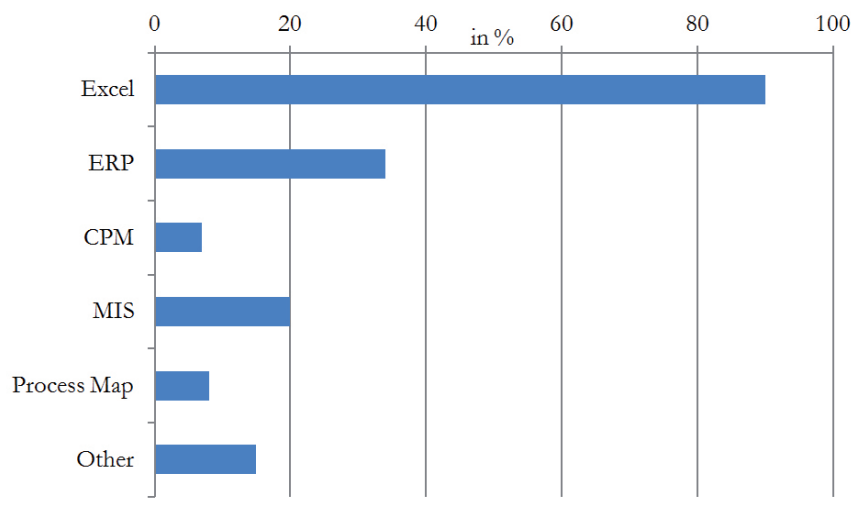

Fig. 5 - Frequency of $S W$ tools for mesuring of performance. Souce: own 


\section{CONCLUSIONS}

Logistic activities of manufacturing organizations are comparable with investigations performed within the scope of the research project finished in 2004; from the view of developments in time, in comparison with the year 2001, moderate increase in frequency of some activities related to the distribution logistics, such as packaging, warehousing and securing transport, and selection of distribution routes, planning of production program, in setting up a plan of supply and placement of orders has occurred. The reasearch confirmed that manufacturing companies are using to a great degree methods of industrial engineering, most notably the following methods: Standardization, Analysis and modelling of business processes, TPM, Study of working methods, KAIZEN and Teams. As for metrics for measuring logistic and manufacturing performance, the most widely used is SWOT analysis and also evaluation of productivity, analysis and measuring of labor, financial analysis and benchmarking comparison. For the evaluation of internal processes of performance of companies, the most widely used criteria are those for costs of internal processes, performance of internal processes, number of employees involved in the internal processes, time of duration of the individual process, size of stocks, and profitability of internal processes.

\section{Acknowledgement:}

The contribution was processed with the support from grant project GAČR 402/09/1739 „Development of a Model for Measuring and Management of Performance of Companies" and of the project IGA/79/FaME/10/ D UTB in Zlín „Influence of the Application of Industrial Engineering on the Production and Logistic Performance of Organizations“.

\section{References:}

1. Blackburn, I., D. (1994). Závod s časem. Praha: Victoria Publishing.

2. Bobák, R. (2004). Příspěvek logistiky a průmyslového inženýrství ke konkurenceschopnosti výrobního systému organizace. Kvalita - Inovace-Prosperita (Quality-Innovation-Prosperity), 8(1), 9-16.

3. Bobák, R. (2007). Výrobní a logistická výkonnost zpracovatelů plastů ve Zlínském kraji. Kvalita, Inovacia, Prosperita (Quality - Innovation - Prosperity),11(1), 1-8.

4. De Toni, A. \& Nassimbeni, G. (1999). Buyer-supplier operational practices, sourcing policies and plant performances: results of an empirical research. International Journal of Production Research, 37(3), 597-619. http://dx.doi.org/10.1080/002075499191698

5. Dilworth, J. B. (1993). Production and Operations Management. Singapore: Mc Graw - Hill co.

6. Fiala, P. (1999). Logistické řetězce a sít’ové produkční systémy. E+M Economics and Management, 2(4), 38-40

7. Frohlich, M. T. \& Westbrook, R. (2001). Arcs of integration: an international study of supply chain strategies. Journal of Operations Management, 19(2), 185-200. http://dx.doi. org/10.1016/S00272-6963(00)00055-3

8. Garcia, F. A, Marchetta, M. G., Camargo, M., Morel, L. \& Forradellas, R. Q (2012). A Framework for measuring logistics performance in the wine industry. Int. J. Production Economics, 135(1), 284-298. http://dx.doi.org/10.1016/j.ijpe.2011.08.003 
9. Gregor, M., Košturiak, J. \& Halušková, M. (1997). Priemyslové inženierstvo-simulácia výrobných systémov. Žilina: Katedra priemyslového inženierstva Strojnickej fakulty Žilinskej university.

10. Gros, I. (1996). Logistikea. Praha: Vydavatelství VŠCHT.

11. Hammer, M. \& Champy, J. (1995). Re - engineering - radikálni prèemèna firmy-manifest revoluce v podnikání. Praha: Management Press.

12. Jirásek, J., A. (2001). Konkurenčnost. Vitězství a porážky na kolbisti trbu. Praha: Professsional Publishing.

13. Kaplan, R. S. \& Norton, D. P. (2000). Balanced Scorecard - Strategický system rízeneni a mèrení výkonnosti podniku. Praha: Management Press.

14. Knápková, A., Pavelková, D. \& Chodúr, M. (2011). Měreni a ř́zeneni výkonnosti podnikủ. Praha: Linde Praha.

15. Li, G., Yang, H., Sun, L. \& Sohal, A.S. (2009). The impact of IT implementation on supply chain integration and performance. International Journal of Production Economics, 120(1), 125-138. http://dx.doi.org/10.1016/j.ijpe.2008.07.015

16. Pernica, P. (1995) Metody v logistice. Logistika, 19(7), 37 - 38.

17. Porter, M. (1995). Konkurenčni výhoda. Praha: Victoria Publishing.

18. Porter, M. (1994). Konkurenční strategie - Metody pro analýzu odvětví a konkurentů. Praha: Victoria Publishing.

19. Prajogo, D. \& Olhager, J. (2012). Supply chain integration and performance: The effects of long-term relationships, information technology and sharing, and logistics integration. International Journal of Production Economics 135(1), 514-522. http://dx.doi.org/10.1016/ j.ijpe.2011.09.001

20. Report of the Presidential Commision of the USA for competitiveness of the industry. Retreived from: http://www.channelingreality.com/Competitiveness/Global_ Competition_New_Reality_typed.pdf

21. Ricardo, D. (1956). Základy politické ekonomie a żdanèní. Praha: SNPL.

22. Samuelson, P.A. \& Nordhaus, W.D. (2005). Economics. Boston: McGraw-Hill.

23. Sheu, C., Yen, H.R. \& Chae, B. (2006). Determinants of supplier-retailer collaboration: evidence from an international study. International Journal of Operations and Production Management, 26(1), 24-49. http://dx.doi.org/10.1108/01443570610637003

24. Schulte, Ch. (1994). Logistikea. Praha: Victoria Publishing.

25. Sixta, J. (2000). Logistika výrobních podniků a vstup ČR do EU. In. E+M Economics and Management, 3(1), 27-30.

26. Skodakova, P., Pavelkova, D. \& Vymola, T. (2008). ICT application for benchmarking of financial performance of clusters. Center for inVestigations into Informations Systems. Retrieved from: http://www.cvis.cz/eng

27. Smith, A. (1958). Pojednání o podstaté a piovodu bohatství národũ. Praha: SNPL.

28. Stevenson, W. J. (2007). Operations management. Boston, MA: McGraw-Hill Publishing.

29. Tomek, J. (1999). Marketing podniku jako koordinator a spolutvůrce konkurenceschopné nabídky v podmínkách globálního trhu. Sbornik préednášek védecké conference Podnik pro tretí tisicileti - Cesty zuysováni konkurenčni schopnosti čskeých primyslových výrobcu na prélomu trétího tisiciletí (pp. 19-37). Zlín: VUT v Brně, Fakulta managementu a ekonomiky ve Zlíně. 
30. Trnka, F. (2004). Výzkum konkurenčni schopnosti českých priomyslových výrobcü-Soubrnná zpráva o rešeni výzkumnébo zámèru (pp. 112-141). Zlín: Univerzita Tomáše Bati ve Zlíně Fakulta managementu a ekonomiky.

31. Tuček, D. \& Holočiová, Z. (2002). Výsledky výžlumu vyư̌ití metod PI v českých podnicich - dílǔi výzkumná zpráva. Zlín: UTB ve Zlíně, FaME.

32. Van Der Vaart, T. \& Van Donk, D. P. (2008). A critical review of survey-based research in supply chain integration. International Journal of Production Economics, 111(1), 42-55.

33. Vytlačil, M., Mašín, I. \& Staněk, M. (1997). Podnik světové trúdy. Geneze productivity a kvality. Liberec: Institut průmyslového inženýrství.

34. Warnecke, H. J., Košturiak, J., Debnar, R., Gregor, M. \& Micieta, B. (2000). Fraktálový podnik. Žilina: Slovenské centrum productivity.

35. Zeleny, M. (2000). Corporate Organism in the Knowledge Environment of the $21 \mathrm{st}$ Century. Conference proceedings International Conference J AKOST 2000, Ostrava.

\section{Contact information}

doc. Ing. Roman Bobák, Ph.D.

Tomas Bata University in Zlin, Faculty of Management and Economics

Mostni 5139, 76001 Zlin, Crech Republic

E-mail:bobak@fame.utb.cr

Ing. Pavlina Pivodová

Tomas Bata University in Zlin, Faculty of Management and Economics

Mostni 5139, 76001 Zlin, Czech Republic

E-mail:pivodova@fame.utb.cz

Ing. Veronika Poláková

Tomas Bata University in Zlin, Faculty of Management and Economics

Mostni 5139, 76001 Zlín, Czech Republic

E-mail:nika.polakova@gmail.com

JEL Classification: L60, M11 